\title{
ENVIRONMENTAL AND AGRICULTURAL BENEFITS OF A MANAGEMENT SYSTEM DESIGNED FOR SANDY LOAM SOILS OF THE HUMID TROPICS ${ }^{(1)}$
}

\author{
Alana das Chagas Ferreira Aguiar ${ }^{(2)}$, Andreia Pereira Amorim( ${ }^{(3)}$, \\ Katia Pereira Coêlho ${ }^{(3)}$ \& Emanoel Gomes de Moura ${ }^{(4)}$
}

\begin{abstract}
SUMMARY
A sustainable management of soils with low natural fertility on family farms in the humid tropics is a great challenge and overcoming it would be an enormous benefit for the environment and the farmers. The objective of this study was to assess the environmental and agronomic benefits of alley cropping, based on the evaluation of $\mathrm{C}$ sequestration, soil quality indicators, and corn yields. Combinations of four legumes were used in alley cropping systems in the following treatments: Clitoria fairchildiana + Cajanus cajan; Acacia mangium + Cajanus cajan; Leucaena leucocephala + Cajanus cajan; Clitoria fairchildiana + Leucaena leucocephala; Leucaena leucocephala + Acacia mangium and a control. Corn was used as a cash crop. The $C$ content was determined in the different compartments of soil organic matter, CEC, available $P$, base saturation, percentage of water saturation, the period of the root hospitality factor below the critical level and corn yield. It was concluded that alley cropping could substitute the slash and burn system in the humid tropics. The main environmental benefit of alley cropping is the maintenance of a dynamic equilibrium between $\mathrm{C}$ input and output that could sustain up to $10 \mathrm{Mg} \mathrm{ha}^{-1}$ of $\mathrm{C}$ in the litter layer, decreasing atmospheric $\mathrm{CO}_{2}$ levels. Alley cropping is also beneficial from the agricultural point of view, because it increases base saturation and decreases physical resistance to root penetration in the soil layer $0-10 \mathrm{~cm}$, which ensures the increase and sustainability of corn yield.
\end{abstract}

Index terms: corn, alley cropping, litterfall, rootability.

\footnotetext{
(1) Recebido para publicação em novembro de 2008 e aprovado em maio de 2009.

(2) Professora do Centro de Ciências Agrárias e Ambientais, Universidade Federal do Maranhão - UFMA. BR 222, km 04, CEP 65500-000 Chapadinha (MA). E-mail: alanaaguiar@elo.com.br

(3) Aluno do Programa de Pós-Graduação em Agroecologia, Universidade Estadual do Maranhão - UEMA. Caixa Postal 3004, CEP 65054-970 São Luís (MA). E-mails: andreiapamorim@terra.com.br; katiapc2004@yahoo.com.br

(4) Professor do Programa de Pós-Graduação em Agroecologia, UEMA. E-mail: egmoura@elo.com.br
} 


\title{
RESUMO: BENEFÍCIOS AMBIENTAIS E AGRONÔMICOS DE UM AGROSSISTEMA DEFINIDO PARA SOLOS DE TEXTURA FRANCO ARENOSA DO TRÓPICO ÚMIDO
}

\begin{abstract}
O manejo sustentável dos solos de baixa fertilidade natural na agricultura familiar do trópico tem sido um grande desafio, que, se vencido, resultará em vantagens para o ambiente e para os agricultores. Este trabalho foi realizado com o objetivo de avaliar os benefícios ambiental e agronômico de um cultivo em aleias, por meio da determinação do C sequestrado, dos indicadores da qualidade do solo e da produtividade da cultura do milho. Foram utilizadas combinações de quatro leguminosas, formando os tratamentos: Clitoria fairchildiana + Cajanus cajan; Acacia mangium + Cajanus cajan; Leucaena leucocephala + Cajanus cajan; Clitoria fairchildiana + Leucaena leucocephala; Leucaena leucocephala + Acacia mangium; e testemunha. O milho foi utilizado como cultura econômica. Foram determinados o teor de C nos vários compartimentos da matéria orgânica do solo, a CTC, o P disponível, a saturação por bases, a percentagem de saturação por água, o período do fator hospitalidade da raiz abaixo do nível critico e a produtividade da cultura do milho. Conclui-se que o cultivo em aleias pode substituir o corte e a queima no trópico úmido com vantagens ambientais, diminuindo a quantidade de $\mathrm{CO}_{2}$ atmosférico por meio da manutenção de um equilíbrio dinâmico entre entrada e saída de C, que pode sustentar até $10 \mathrm{Mg} \mathrm{ha}^{-1}$ desse elemento na liteira. Do ponto de vista agronômico, os benefícios do cultivo em aleias foram o aumento da saturação por bases e a diminuição da resistência física à penetração das raízes na camada de o a $10 \mathrm{~cm}$, o que propiciou o aumento e a sustentação da produtividade da cultura do milho.
\end{abstract}

Termos de indexação: milho, cultivo em aleias, liteira, enraizabilidade.

\section{INTRODUCTION}

The sustainable management of soils with low natural fertility is a major challenge for family agricultural farms in the humid tropics. The burning of vegetation and use of the resulting ashes as nutrient source has long been the main strategy used by family farmers to make up for fertility deficiencies of the highly weathered soils derived from sedimentary rocks. This is the case on most farms in the tropical region (Brady, 1996). Commonly known as slash and burn agriculture, this system no longer meets the needs of family farmers: its negative effects on the local and global environment outweigh any social benefits for the rural communities. In a local context, the rise in demand for farm land and population increase have led to ever-shorter fallow periods between burnings. The most fire-susceptible species are eliminated, which allows more resistant species to dominate, thereby reducing biodiversity and impoverishing the ecosystem (Moura et al., 2009a).

The global impact of biomass burning on $\mathrm{C}$ emission must also be considered. Carbon emission from itinerant farming can reach $1.1 \mathrm{Pg}$ per year, which means that is responsible for $25 \%$ of the world's total $\mathrm{CO}_{2}$ emission (Fearnside, 2000). In Brazil, one of the seven largest emitting countries (Walser, 2008), $70 \%$ of the total $\mathrm{CO}_{2}$ emission comes from uncontrolled fires, which release approximately $69 \mathrm{t} \mathrm{ha}^{-1}$ of $\mathrm{CO}_{2}$ of burned forest (Fearnside, 2002). Therefore, finding an alternative for slash-and-burn agriculture is justified firstly by the pressing need to increase agricultural productivity, and secondly by the urgency to reduce the environmental impact of burning. Unfortunately, none of the alternatives to burning increases productivity or ensures sustainability of agrosystems in the humid tropics. Most alternatives replicate practices established in other regions and are based on soil tillage and saturation with soluble nutrients (Moura et al., 2009b).

To improve and maintain soil fertility in this region, no-tillage and mulching are more important than other common practices, such as plow and chisel, because they contribute to the formation of a litter layer that is more favorable to root growth. In an experiment conducted in a sandy loam soil in the preAmazon region, in Maranhão State, a soil cover with $3 \mathrm{Mg} \mathrm{ha}^{-1}$ of dry biomass had an effect on corn cultivation that was twice as great as the increase produced by liming. Base saturation increased from 28 to $73 \%$, as recommended in manuals for soil management in Southeastern Brazil (Moura et al., 2008). The challenge to manage this land sustainably also provides a great opportunity to adopt agrosystems that enhance soil fertility, while reducing the impact of atmospheric $\mathrm{C}$ emissions, by reducing emissions from biomass burning and by retaining $\mathrm{C}$ within soil organic matter (SOM).

Several comparative studies by Oelbermann et al. (2004) have indicated that with the use of alley cropping, the quantity of $\mathrm{C}$ applied to the soil can vary from 0.3 to $4.6 \mathrm{Mg} \mathrm{ha}^{-1}$ year $^{-1}$, according to the plant 
age, plant spacing and soil classes. In addition to the quantity and quality of biomass applied, the increment of SOM also varies according to the decomposition conditions as given by the soil properties and management (Albrecht \& Kandji, 2003). Moreover, biomass application is only the first step in a process of $\mathrm{C}$ sequestration, which can only be considered successful, if the balance between the initial and final stocks is positive after several decades (Feller et al., 2001). Kang (1997) and Fassbender (1998) reported increases of 37 and $21 \%$ in soil C contents, respectively, as a result of alley cropping. However, Young (1997) stated that changes in the soil $\mathrm{C}$ stock can only be observed after a period of at least 10 years.

Several authors, such as Buresh \& Tian (1998) and Vanlauwe et al. (2005), claimed that the use of alley cropping improved soil fertility and increased crop productivity. However, the addition of inorganic fertilizers (mainly phosphates) has invariably been recommended to promote good recycling within the system, especially for $\mathrm{N}$ and $\mathrm{Ca}$. Even though the usefulness of alley cropping for farming is well-known, its impact on various $\mathrm{C}$ pools and effects on soil fertility and crop productivity in humid tropical environments have yet to be assessed. The aim of this study was to evaluate the environmental and agronomic benefits of an alley cropping system by measuring the $\mathrm{C}$ amount sequestered, and the productivity of corn cultivation, in a humid tropical sandy-loam soil.

\section{MATERIAL AND METHODS}

The experiment began in 2002, at the Universidade Estadual do Maranhão (latitude $2^{\circ} 30$ ' S, longitude $\left.44^{\circ} 18^{\prime} \mathrm{W}\right)$. The soil was classified as an Ultisol Typic Paleustult, with the following textural characteristics: coarse sand 260, fine sand 560, silt 80, and clay $100 \mathrm{~g} \mathrm{~kg}^{-1}$. The area was limed in January 2002, with $1 \mathrm{Mg} \mathrm{ha}^{-1}$ of surface-applied lime, corresponding to 390 and $130 \mathrm{~kg} \mathrm{ha}^{-1}$ of Ca and $\mathrm{Mg}$, respectively. Six months after liming, at the time of sowing alley cropping, four composite soil samples of 20 sub-samples were randomly collected with a duty auger across the field using the ' $W$ ' sampling pattern in four layers (0-5, $5-10,10-15$ and $15-20 \mathrm{~cm})$, as recommended by the IAC (2001) (Table 1).

An experimental design of randomized blocks was used, with six combinations and four replications. Four leguminous species were used for the alley cropping, including two with high-quality residue Leucaena leucocephala (leucaena) and Cajanus cajan (pigeon pea), and two with low-quality residue - Clitoria fairchildiana (clitoria), and Acacia mangium (acacia). The leguminous species were grown at a distance of $0.5 \mathrm{~m}$ between plants, in $21 \times 4 \mathrm{~m}$ plots, in mixed rows, so that each plot received both residue types, resulting the following treatments, consisting in the combination
Table 1. Chemical analysis of the soil, six months after liming at the time of sowing alley cropping

\begin{tabular}{|c|c|c|c|c|}
\hline \multirow{2}{*}{ Soil attribute } & \multicolumn{4}{|c|}{ Depth (cm) } \\
\hline & $\mathbf{0}-\mathbf{5}$ & $5-10$ & $10-15$ & $15-20$ \\
\hline Organic matter $\left(\mathrm{g} \mathrm{dm}^{-3}\right)$ & 22 & 16 & 12 & 10 \\
\hline $\mathrm{pH}\left(\mathrm{CaCl}_{2}\right)$ & 6.4 & 5.9 & 4.8 & 4.2 \\
\hline $\mathrm{P}\left(\mathrm{mg} \mathrm{dm} \mathrm{dm}^{-3}\right)$ & 4 & 3 & 2 & 1 \\
\hline $\mathrm{K}^{+}\left(\mathrm{mmol}_{\mathrm{c}} \mathrm{dm}^{-3}\right)$ & 0.4 & 0.5 & 0.4 & 0.4 \\
\hline $\mathrm{Ca}^{2+}\left(\mathrm{mmol}_{\mathrm{c}} \mathrm{dm}^{-3}\right)$ & 19 & 10 & 5 & 3 \\
\hline $\mathrm{Mg}^{2+}\left(\mathrm{mmol}_{\mathrm{c}} \mathrm{dm}^{-3}\right)$ & 11 & 9 & 5 & 2 \\
\hline Potencial acidity $\left(\mathrm{mmol}_{\mathrm{c}} \mathrm{dm}^{-3}\right)$ & 10 & 13 & 20 & 24 \\
\hline Sum of bases $\left(\mathrm{mmol}_{\mathrm{c}} \mathrm{dm}^{-3}\right)$ & 30.4 & 19.5 & 10.4 & 5.4 \\
\hline $\mathrm{CEC}\left(\mathrm{mmol}_{\mathrm{c}} \mathrm{dm}^{-3}\right)$ & 40.4 & 32.5 & 30.4 & 29.4 \\
\hline Bases saturation (\%) & 75 & 60 & 34 & 18 \\
\hline
\end{tabular}

of two leguminous species: Clitoria + Pigeon pea $(\mathrm{C}+\mathrm{P})$; Acacia + Pigeon pea $(\mathrm{A}+\mathrm{P})$; Clitoria + Leucaena $(\mathrm{C}+\mathrm{L})$; Leucaena + Acacia (L+A) and Control (no legumes).

Corn (cultivar AG 1051) was sown in each January between 2002 and 2007, in a $90 \times 20 \mathrm{~cm}$ spacing. The soil was fertilized with $25 \mathrm{~kg} \mathrm{ha}^{-1} \mathrm{~N}, 62 \mathrm{~kg} \mathrm{ha}^{-1} \mathrm{P}$, $37.5 \mathrm{~kg} \mathrm{ha}^{-1} \mathrm{~K}$ and $1.25 \mathrm{~kg} \mathrm{ha}^{-1} \mathrm{Zn}$. In addition, $30 \mathrm{~kg} \mathrm{ha}{ }^{-1} \mathrm{~N}$ was applied in the form of ammonium sulfate, when the fourth pair of corn leaves emerged. Due to the poor growth performance of the legumes in 2003, pruning only was made in January 2004, 2005 and 2006 , at a height of $50 \mathrm{~cm}$, immediately after corn germination. The biomass of legume pruning was distributed homogeneously over all plots of the same treatment; no statistical analyses were applied for evaluation. A $2 \mathrm{~kg}$ sample of cut legume was collected from each treatment, with three replications per plot and oven-dried at $60{ }^{\circ} \mathrm{C}$ with forced air circulation to constant mass for $\mathrm{C}$ determination.

The litterfall was measured randomly in three samples per plot, in April 2007, in a $0.25 \times 0.25 \mathrm{~m}$ area. Organic matter was separated by soil physical fractionation based on density $\mathrm{NaI}$ solution of $1.80 \mathrm{~g} \mathrm{~cm}^{-3}$ density, and particle size separation of the fraction, as described by Machado (2002). Wet oxidation with potassium dichromate was used for $\mathrm{C}$ analysis of each soil fraction $\left(\mathrm{C}_{\mathrm{sf}}\right)$ following the method described by Embrapa (1997), and legume biomass $\left(\mathrm{C}_{\mathrm{b}}\right)$ and litterfall $\left(\mathrm{C}_{\mathrm{l}}\right)$ as described by Sparks (1996) The $\mathrm{C}$ stocks were estimated as follows:

$\mathrm{C}_{\mathrm{b}}\left(\mathrm{Mg} \mathrm{ha}^{-1}\right)=$ carbon content $\mathrm{x}$ legume biomass $\left(\mathrm{Mg} \mathrm{ha}^{-1}\right) \times 10^{-2}$;

$\mathrm{C}_{\mathrm{l}}\left(\mathrm{Mg} \mathrm{ha}^{-1}\right)=$ carbon content $\mathrm{x}$ litterfall mass $\left(\mathrm{Mg} \mathrm{ha}^{-1}\right) \times 10^{-2}$;

$\mathrm{C}_{\mathrm{sf}}\left(\mathrm{Mg} \mathrm{ha}^{-1}\right)=$ carbon content $\mathrm{x} 10 \mathrm{x}$ soil density $\left(\mathrm{g} \mathrm{cm}^{-3}\right)$. 
Soil samples for the evaluation of the percentage of water saturation and soil density were collected in $100 \mathrm{~cm}^{3}$ volumetric rings, in April 2007. These measurements of physical indicators were repeated three times per plot, between 5 and $12 \mathrm{~cm}$ soil depth, using the method described by Thomasson (1978). For chemical analysis and organic matter content, soil samples were collected from the layer $0-10 \mathrm{~cm}$, in April 2007. The P-resin, $\mathrm{K}^{+}, \mathrm{Ca}^{2+}, \mathrm{Mg}^{2+}$, and $\mathrm{H}+\mathrm{Al}$ content was measured using the IAC (2001) method. The cation exchange capacity (CEC) was calculated according to Raij et al., (2001), as follows: $\mathrm{K}^{+}+\mathrm{Ca}^{2+}+$ $\mathrm{Mg}^{2+}+(\mathrm{H}+\mathrm{Al})$, base saturation $(\mathrm{BS})=\mathrm{K}^{+}+\mathrm{Ca}^{2+}+$ $\mathrm{Mg}^{2+}$ and base saturation percentage (BSP) $=\mathrm{BS} / \mathrm{CEC}$ x 100. Total contents of overall N, P, K, Ca, and Mg in the leguminous residues were measured using the method described by Tedesco et al. (1995). Penetration resistance was measured on a daily basis, from the $10^{\text {th }}$ to the $70^{\text {th }}$ days after corn germination, down to a depth of $10 \mathrm{~cm}$, using a digital Field Scout Penetrometer Brand (Spectrum Technologies, East Plainfield, USA), with interval variations of $2.5 \mathrm{~cm}$. Two $\mathrm{mPa}$ was used as the critical limit of the root hospitality factor. To analyze corn production, the total grain mass of 40 plants was measured in two rows in the center of the plots.

Analysis of Variance (ANOVA), followed by Tukey test $(p<0.05)$ were performed using SAEG 9.1 (2007).

\section{RESULTS AND DISCUSSION}

\section{Environmental benefit}

Carbon accumulated in the legume biomass in the fourth year was much higher than values reported by Oelbermann et al. (2004) for subtropical regions (0.3-4.6 against 4-12 $\mathrm{Mg} \mathrm{ha}^{-1}$ ) (Figure 1). On the other hand, differences in productivity between species did not limit the possibility of using plants of different residue quality collectively in order to obtain both soil cover and high efficiency in nutrient recycling. Even the combination of clitoria and leucaena $(\mathrm{C}+\mathrm{L})$, which was agronomically most interesting because it produces a well-balanced mixture of high and low quality residues, accumulated more than $7 \mathrm{t} \mathrm{ha}^{-1}$ year ${ }^{-1}$ of $\mathrm{C}$, after four years of cutting.

One of the most important characteristics of alley cropping is the constant soil coverage with a permanent litter layer of surface-applied plant biomass. In our experiment, the variation in the $\mathrm{C}$ amount contained in the litter was more related to the resistance of branches and stalks than the quantity of applied residues (Table 2). Therefore, leucaena and acacia species were the main contributors to the high residue production, which suggests that when combined, these species can be more useful for farming and the environment than the other legumes under study.

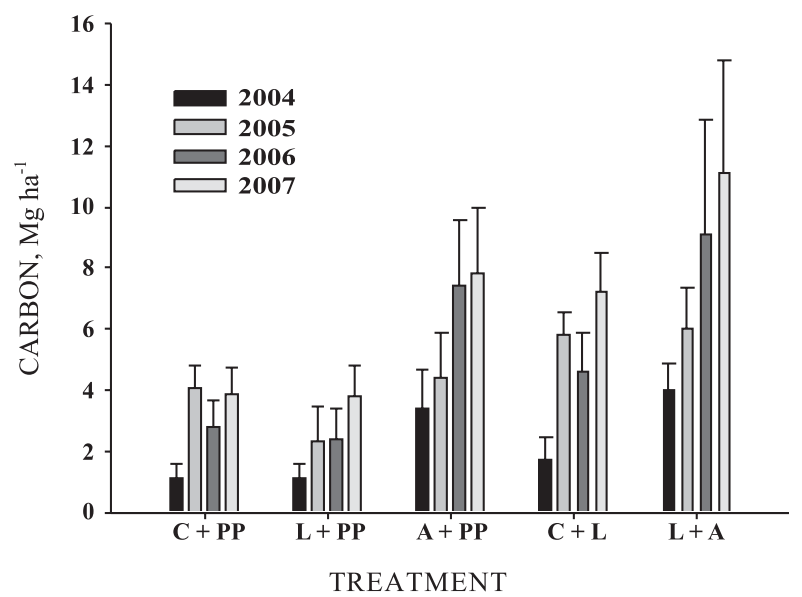

Figure 1. Carbon stocks in leguminous mixtures under different treatments for four years. $C+P P$ : clitoria + pigeon pea; $\mathrm{L}+\mathrm{PP}$ : leucaena + pigeon pea; $\mathrm{A}+\mathrm{PP}$ : acacia + pigeon pea; $\mathrm{C}+\mathrm{L}$ : clitoria + leucaena; $\mathrm{L}+\mathrm{A}$ : leucaena + acacia.

The free light fraction of SOM of the control plot differed from the treatments $\mathrm{L}+\mathrm{PP}$ and $\mathrm{A}+\mathrm{PP}$ (Table 2). In this case, there are both agronomic and environmental benefits because these differences are due to the constant addition of residues and are important for soil quality (Shepherd et al., 2002). The same practice could have a further environmental benefit, because a large quantity of $\mathrm{C}$ is retained within the system, which compensates for C losses caused by decomposition.

Environmentally, it would be preferable that C would be stored in the pools with the most stable SOM. According to Feller \& Beare (1997), the mean residence time of SOM fractions decreases with the increase in soil particle size. In this experiment, there were no differences between treatments with legumes and control in relation to organic matter pools associated with mineral fractions in the soil. The same result was found with humic fraction (Table 2). Environmental factors, such as water, oxygen and nutrient availability and high temperatures - all of which were present in this experiment - can accelerate residue decomposition. They can also eliminate the differences among systems of soil management as these fractions of organic matter (Christensen, 2000). These results reduce the scope of using no-tillage in alley cropping in order to raise levels of stable fractions of organic matter under the conditions tested herein. This system, therefore, can be an environmentally alternative for farming in the humid tropics, only due to high productivity of leguminous biomass and the dynamic between the content of carbon maintained in a steady-state.

\section{Agronomic benefits}

Another important advantage of alley cropping is that it contributes to an enhanced sustainability of 
the system, by recycling nutrients from the deeper to the upper layers (Mafongoya et al., 2006). In this experiment, more significant amounts of $\mathrm{Ca}^{2+}$ and $\mathrm{K}^{+}$ were recycled by the leguminous than of $\mathrm{Mg}$ and $\mathrm{P}$ (Table 3). The most efficient treatments were leucaena and acacia due to high quantity of biomass produced by acacia and high concentrations of $\mathrm{Ca}^{2+}$ and $\mathrm{K}^{+}$ contained in leucaena residues. In terms of improving rootability conditions, the quantity of Ca recycled is important, given its effect on base saturation, which was $46 \%$ after five years in leucaena plus acacia treatments and $21.1 \%$ in the control.

Furthermore, alley cropping produced a higher quantity of $\mathrm{N}$ than required for a corn crop, particularly in the combinations of leucaena with acacia or clitoria where more than $220 \mathrm{~kg} \mathrm{ha}^{-1}$ year-1 $^{-1}$ of $\mathrm{N}$ was applied (Table 3). Two aspects of the effect that this increase may have on a crop need to be considered: firstly, the absence of complete synchronization between the $\mathrm{N}$ release and crop demands. In the alley cropping system, the crop recovers about $20 \%$ of $\mathrm{N}$ directly from residues, as confirmed by Buresh \& Tian (1998); secondly, major $\mathrm{N}$ uptake efficiency depends on the conditions of rootability. It has been shown that the greater availability of $\mathrm{N}$ could compensate one higher levels of soil compaction, which indicates that these factors are closely related (Wong \& Asseng, 2007). In our experiment, higher percentages of water saturation were observed in legume-treated areas. This effect can be explained by the greater levels of light fraction of organic matter resulting from the continuous residue addition. This practice in sandy loam soil promotes the formation of an "ephemeral structure", comprising unstable aggregates that increase the soil water retention capacity and contribute to an environment favorable to root growth, according to Shepherd et al. (2002).

In our experiment, the control soil was treated only twice with $\mathrm{N}$ : at planting and when the fourth pair of leaves emerged. Therefore, two main factors

Table 2. Carbon stocks in the litter layer and different fractions of soil organic matter separated by physical fractionation at $0-10 \mathrm{~cm}$ depth

\begin{tabular}{|c|c|c|c|c|c|c|}
\hline \multirow[b]{2}{*}{ Carbon fraction } & \multicolumn{6}{|c|}{ Treatment } \\
\hline & $\mathrm{C}+\mathrm{PP}$ & $\mathbf{L}+\mathbf{P P}$ & $\mathbf{A}+\mathbf{P P}$ & $\mathrm{C}+\mathrm{L}$ & $\mathbf{L}+\mathbf{A}$ & Control \\
\hline & \multicolumn{6}{|c|}{$-\mathrm{Mg} \mathrm{ha}^{-1}$} \\
\hline Litter & $3.72 \mathrm{~d}$ & $7.32 \mathrm{c}$ & $6.57 \mathrm{c}$ & $8.86 \mathrm{~b}$ & $10.67 \mathrm{a}$ & $0.86 \mathrm{e}$ \\
\hline Free Light Fraction & $0.16 \mathrm{ab}$ & $0.22 \mathrm{a}$ & 0.19 a & $0.18 \mathrm{ab}$ & $0.18 \mathrm{ab}$ & $0.15 \mathrm{~b}$ \\
\hline Intra-aggregate light fraction & $0.03 \mathrm{~ns}$ & $0.03 \mathrm{~ns}$ & $0.04 \mathrm{~ns}$ & $0.04 \mathrm{~ns}$ & $0.03 \mathrm{~ns}$ & $0.02 \mathrm{~ns}$ \\
\hline Sand fraction & $0.72 \mathrm{~ns}$ & $0.53 \mathrm{~ns}$ & $0.90 \mathrm{~ns}$ & $0.84 \mathrm{~ns}$ & $0.76 \mathrm{~ns}$ & $0.57 \mathrm{~ns}$ \\
\hline Silt fraction & $2.49 \mathrm{~ns}$ & $2.17 \mathrm{~ns}$ & $2.45 \mathrm{~ns}$ & $2.15 \mathrm{~ns}$ & $1.99 \mathrm{~ns}$ & $2.40 \mathrm{~ns}$ \\
\hline Clay fraction & $2.49 \mathrm{~ns}$ & $2.93 \mathrm{~ns}$ & $2.34 \mathrm{~ns}$ & $2.61 \mathrm{~ns}$ & $2.46 \mathrm{~ns}$ & $3.64 \mathrm{~ns}$ \\
\hline
\end{tabular}

Means in a row followed by the same letter are not significantly different at $5 \%$ in the Tukey test. C+PP: clitoria + pigeon pea; L + PP: leucaena + pigeon pea; A + PP: acacia + pigeon pea; C+L: clitoria + leucaena; L + A: leucaena + acácia. ns: no significant.

Table 3. Total nutrient content recycled by legumes and applied through legume residues, litter quantity and soil quality indicators for the treatments, after five years

\begin{tabular}{|c|c|c|c|c|c|c|}
\hline & \multicolumn{6}{|c|}{ Tr eatment } \\
\hline & $\mathbf{C}+\mathbf{P P}$ & $\mathbf{L}+\mathbf{P P}$ & $\mathrm{A}+\mathrm{PP}$ & $\mathbf{C}+\mathrm{L}$ & $\mathbf{L}+\mathbf{A}$ & Control \\
\hline $\mathrm{N}\left(\mathrm{kg} \mathrm{ha}^{-1}\right)$ & 530.94 & 755.85 & 859.85 & 1146.50 & 1475.40 & - \\
\hline $\mathrm{P}\left(\mathrm{kg} \mathrm{ha}^{-1}\right)$ & 33.28 & 33.36 & 28.94 & 52.84 & 48.49 & - \\
\hline $\mathrm{Ca}(\mathrm{kg} \mathrm{ha} \cdot 1)$ & 326.71 & 338.25 & 741.34 & 597.52 & 1012.14 & - \\
\hline $\mathrm{Mg}\left(\mathrm{kg} \mathrm{ha}^{-1}\right)$ & 63.92 & 113.29 & 79.62 & 167.45 & 183.14 & - \\
\hline $\mathrm{K}\left(\mathrm{kg} \mathrm{ha}^{-1}\right)$ & 157.01 & 152.33 & 253.34 & 269.23 & 365.55 & - \\
\hline Lit t er $\left(\mathrm{Mg} \mathrm{ha}^{-1}\right)$ & $7.93 \mathrm{~d}$ & $12.25 \mathrm{c}$ & $12.78 \mathrm{c}$ & $17.94 \mathrm{~b}$ & $21.42 \mathrm{a}$ & $1.96 \mathrm{e}$ \\
\hline Bases saturation in $0-5 \mathrm{~cm}$ depth & $37.5 \mathrm{~b}$ & $35.0 \mathrm{~b}$ & 42.0 & $31.0 \mathrm{~b}$ & $46.0 \mathrm{a}$ & $21.0 \mathrm{c}$ \\
\hline $\begin{array}{l}\text { Water saturation percentage }\left(\mathrm{m} \mathrm{m}^{-3}\right) \text {, } \\
\text { in } 5-12 \mathrm{~cm} \text { depth }\end{array}$ & $41.5 \mathrm{a}$ & $41.4 \mathrm{a}$ & $41.6 \mathrm{a}$ & $40.4 \mathrm{a}$ & $42.5 \mathrm{a}$ & $33.8 \mathrm{~b}$ \\
\hline
\end{tabular}

Means in a row followed by same letter are not significantly different at $5 \%$ in the Tukey test. 
contribute for corn associated with legumes to make use of $\mathrm{N}$ : a greater and better distribution of the $\mathrm{N}$ derived from residue decomposition over a long growth period, and a better ability of the roots to make use of the $\mathrm{N}$ because the root zone environment is more favorable.

Undoubtedly, the main agronomic benefit of alley cropping in the humid tropics is the possibility of maintaining the temperature and humidity at the soil surface through the mulch, as Lal (1979) has shown. In the sandy loam soil of Maranhão State, this is fundamental, because soil under drought tends to harden, due to the high degree of cohesion of the predominating fine sand (Moura et al., 2008). In addition, low levels of free Fe and organic matter contribute to increased cohesion and penetration resistance in soils of a fragile nature when humidity declines (Becher et al., 1997). Thus, the principal effect of the mulch is to reduce evapotranspiration, which delays soil drying and hardening, in periods without rain. Therefore the mulch affects rootability because it reduces the restraints imposed by soil layers on potential root growth and improves the "root hospitality factor" (Wong \& Asseng, 2007). In this experiment, the variations in the number of days in which the root hospitality factor fell below the critical level of $2 \mathrm{mPa}$ (Figure 2) showed the importance of the amount of litter layer on the soil root growth capacity. In the control plot, even the layer between 0 and $5 \mathrm{~cm}$ showed three days of stress after one week without rain.

However, the agronomical advantage of applying residues must be assessed for its effect on the cash crop, as a consequence of improvements in soil fertility. The improved performance of corn cultivation in this experiment shows that the effect of residues was clearly significant and cumulative (Figure 3). In the plots without residue addition, even with liming and

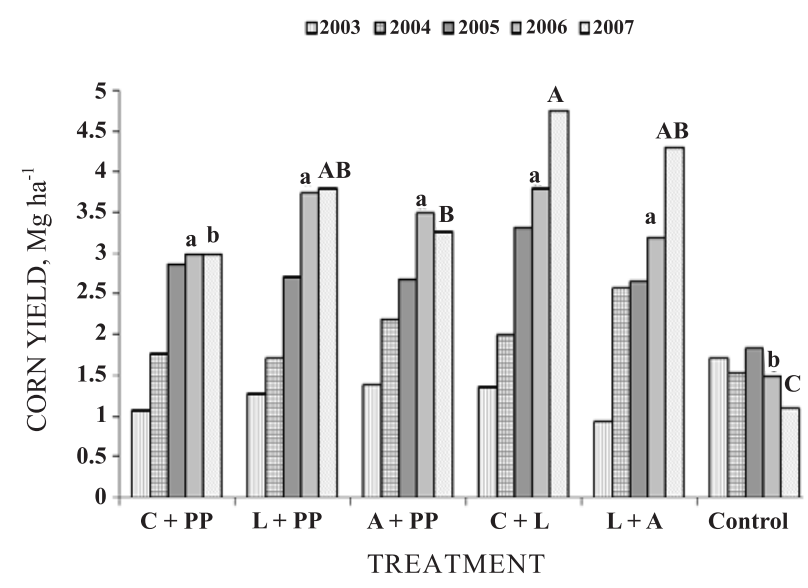

Figure 3. Corn yield over five years. Means for the same letters for all treatments, lower-case for 2006 and upper-case for 2007 , did not differ significantly from each other (Tukey test at $5 \%$ ). C+PP: clitoria + pigeon pea; L+PP: leucaena + pigeon pea; $\mathrm{A}+\mathrm{PP}$ : acacia + pigeon pea; $\mathrm{C}+\mathrm{L}$ : clitoria + leucaena; L+A: leucaena + acacia.

regular fertilization, there was no increase in corn yield, indicating that these practices alone are not enough to increase soil fertility in this area. On the other hand, in all plots with residues, there were significant increases in corn yield from the fourth year onwards. The plots with leucaena are outstanding examples, because they produced three times as much corn as the control plots from the fourth year onwards.

The treatment leucaena with clitoria resulted in the greatest agronomic benefits. These results mean that a more balanced mixture of low and high quality residues may be more beneficial for the agronomic yields of the system.

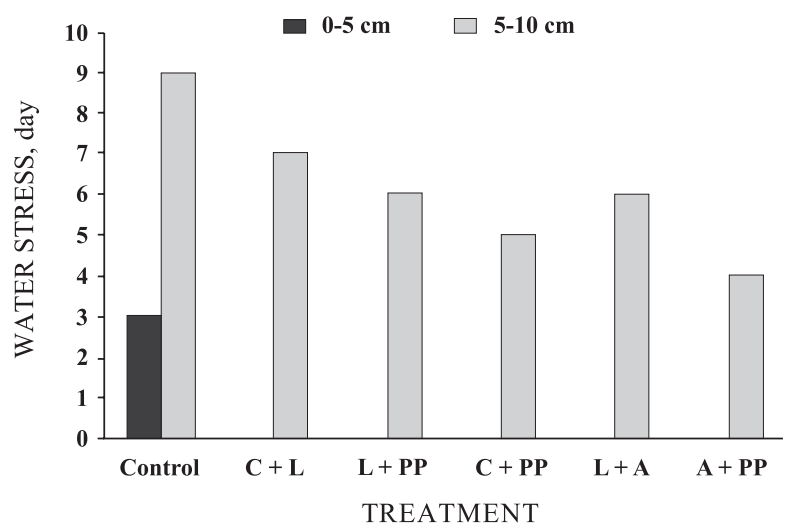

Figure 2. Days in which the root hospitality factor was below the critical level in the soil layer 0 $10 \mathrm{~cm}$. C+PP: clitoria + pigeon pea; $L+P P$ : leucaena + pigeon pea; $\mathrm{A}+\mathrm{PP}$ : acacia + pigeon pea; $C+L$ : clitoria + leucaena; $L+A$ : leucaena + acacia.

\section{CONCLUSIONS}

1. Alley cropping is a potential substitute for slash and burn agriculture in the humid tropics with both environmental and agronomic advantages, due to its ability to produce a large amount of residues on the soil surface and its effect on the increase of economic crop productivity in the long term. Regarding $\mathrm{C}$ sequestration, however, the environmental advantages of this system during the first five years are restricted to the maintenance of a dynamic equilibrium between $\mathrm{C}$ input and output at the soil surface, and the avoidance of the resulting $\mathrm{C}$ emissions, when compared to the regionally predominant slash and burn systems.

2. From an agronomic point of view, the main benefits of alley cropping are the recycling of $\mathrm{Ca}$ and $\mathrm{N}$ and the enhancing of soil water retention capacity. 
Crops could benefit from improved rootability in the $0-10 \mathrm{~cm}$ layer, because of the increase in percent base saturation and the decrease in physical resistance to root penetration.

\section{ACKNOWLEDGEMENTS}

The authors acknowledge Conselho Nacional de Desenvolvimento Científico e Tecnológico (CNPq) and Fundação de Amparo à Pesquisa e ao Desenvolvimento Científico e Tecnológico do Maranhão (FAPEMA) for financial support.

\section{LITERATURE CITED}

ALBRECHT, A. \& KANDJI, S.T. Carbon sequestration in tropical Agroforestry systems. Agric. Ecosyst. Environ., 99:15-27, 2003

BECHER, H.H.; BREUER, J. \& KLINGLER, B. An index value for characterizing hardsetting soils by fall-cone penetration. Soil Technol., 10:47-56, 1997.

BRADY, N.C. Alternatives to slash-and-burn: A global imperative. Agric. Ecosyst. Environ., 58:3-11, 1996.

BURESH, R.J. \& TIAN, G. Soil improvement by trees in subSaharan Africa. Agrofor. Syst., 38:51-76, 1998.

CHRISTENSEN, B.T. Organic matter in soil: Structure, function and turnover. Tjele, Dias, 2000. 187p.

EMPRESA BRASILEIRA DE PESQUISA AGROPECUÁRIA EMBRAPA. Centro Nacional de Pesquisas de Solos. Manual de métodos de análise de solos. Rio de Janeiro, 1997. $212 p$

FASSBENDER, H.W. Long-term studies of soil fertility in cacao-shade trees- agroforestry systems: Results of 15 years of organic matter and nutrients research in Costa Rica. In: SCHULTE, A. \& RUHUJAT, D., eds. Soils of tropical forest ecosystems: Characteristics, ecology and management. Berlin, Springer Verlag, 1998. p.150158.

FEARNSIDE, P. Global warming and tropical land-use change: Greenhouse gas emissions from biomass burning, decomposition and soils in forest conversion, shifting cultivation and secondary vegetation. Climatic Change, 46:115-158, 2000.

FEARNSIDE, P. Fogo e emissão de gases de efeito estufa dos ecossistemas florestais da Amazônia Brasileira. Estudos Avançados, 16:99-123, 2002.

FELLER, C. \& BEARE, M.H. Physical control of soil organic matter dynamics in the tropics. Geoderma, 79:69-116, 1997.
FELLER, C.; ALBRECHT, A.; BLANCHART, E.; CABIDOCHE, Y.M.; CHEVALLIER, T.; HARTMANN, C.; ESCHEN BRENNER, V.; LARRE-LARROUY, M.C. \& NDANDOU, J.F. Soil carbon sequestration in tropical areas: General considerations and analysis of some edaphic determinants for Lesser Antilles soils. Nutr. Cycl. Agroecosyst., 61:19$31,2001$.

INSTITUTO AGRONÔMICO DE CAMPINAS - IAC. Análise química para avaliação da fertilidade de solos tropicais. In: RAIJ, B.van; ANDRADE, J.C.; CANTARELLA, H. \& QUAGGIO, J.A., eds. Campinas, 2001. 285p.

KANG, B.T. Alley cropping - soil productivity and nutrient recycling. For. Ecol. Manag., 91:75-82, 1997.

LAL, R. Soil temperature, soil moisture and maize yield from mulched and unmulched tropical soils. Plant Soil, 40:129143,1979

MACHADO, P.L.O.A. Fracionamento físico do solo por densidade e granulometria para a quantificação de compartimentos da matéria orgânica do solo - um procedimento para a estimativa pormerizada do sequestro de carbono pelo solo. Rio de Janeiro, Empresa Brasileira de Pesquisa Agropecuária, 2002. 6p. (Comunicado Técnico, 9)

MAFONGOYA, P.L.; BATIONO, A.; KIHARA, J. \& WASWA, B.S. Appropriate technologies to replenish soil fertility in southern Africa. Nutr. Cycl. Agroecosyst., 76:137-151, 2006 .

MOURA, E.G.; ARAÚJO, J.R.G.; MONROE, P.H.M.; NASCIMENTO, I.O. \& AGUIAR, A.C.F. Patents on periphery of the Amazon rainforest. Recent Patents on Food, Nutrition \& Agriculture, 1:142-148, 2009a.

MOURA, E.G.; COELHO, K.P.; FREITAS, I.C. \& AGUIAR, A.C.F. Chemical and physical fertility indicators of a weakly-structured Ultisol after liming and mulching. Sci. Agri., 66:800-805, 2009b.

MOURA, E.G.; ALBUQUERQUE, J.M. \& AGUIAR, A.C.F. Growth and productivity of corn as affected by mulching and tillage in alley cropping systems. Sci. Agric., 65:204208,2008

OELBERMANN, M.; VORONEY, R.P. \& GORDON, A.M Carbon sequestration in tropical and temperature agroforestry systems: A review with examples from Costa Rica and Southern Canada. Agric. Ecosyst. Environ., 104:359-377, 2004.

RAIJ, B.van; ANDRADE, J.C.; CANTARELLA, H. \& QUAGGIO, J.A. Análise química para avaliação da fertilidade de solos tropicais. Campinas, Instituto Agronômico de Campinas, 2001. 285p.

SISTEMA PARA ANÁLISES ESTATÍSTICAS - SAEG. Versão 9.1. Viçosa, MG, Fundação Arthur Bernardes/Universidade Federal de Viçosa, 2007.

SPARKS, D.L. Methods of soil analysis: Chemical methods. Madison, SSSA, 1996. Part 3. p.995-1000. (Book Series, 5)

SHEPHERD, M.A.; HARRISON, R. \& WEBB, J. Managing soil organic matter - implications for soil structure on organic farms. Soil Use Manag., 18:284-292, 2002. 
TEDESCO, M.J.; GIANELLO, C.; BISSANI, C.A.; BOHNEN, H. \& VOLKWEISS, S.J. Análises de solos, plantas e outros materiais. 2.ed. Porto Alegre, Universidade Federal do Rio Grande do Sul, 1995. 174p. (Boletim Técnico, 5)

THOMASSON, A.J. Towards an objective classification of soil structure. J. Soil Sci., 29:38-46, 1978.

VANLAUWE, B.; DIELS, J.; SANGINGA, N. \& MERCKX, R. Long-term integrated soil fertility management in South western Nigeria: Crop performance and impact on the soil fertility status. Plant Soil, 273:337-354, 2005.
WONG, M.T.F. \& ASSENG, S. Yield and environmental benefits of ameliorating subsoil constraints under variable rainfall in a Mediterranean environment. Plant Soil, 297:29-42, 2007.

YOUNG, A. Agroforestry for soil management. London, Cab International, 1997. 307p.

WALSER, M.L. Greenhouse gas emissions: Perspectives on the top 20 emitters and developed versus developing nations. In: CUTLER, J., ed. Cleveland Encyclopedia of Earth. Washington, National Council for Science and the Environment, 2008. p.1-6. 